Better Safe Than Sorry 



\section{Better Safe Than Sorry}

THE IRONIES OF LIVING WITH THE BOMB

Michael Krepon 
Stanford University Press

Stanford, California

(C) 2009 by the Board of Trustees of the Leland Stanford Junior University.

All rights reserved.

No part of this book may be reproduced or transmitted in any form or by any means, electronic or mechanical, including photocopying and recording, or in any information storage or retrieval system without the prior written permission of Stanford University Press.

Printed in the United States of America on acid-free, archival-quality paper

Library of Congress Cataloging-in-Publication Data

Krepon, Michael, 1946-

Better safe than sorry : the ironies of living with the bomb / Michael Krepon.

p. cm.

"A Henry L. Stimson Center Book."

Includes bibliographical references and index.

ISBN 978-0-8047-6063-8 (hbk. : alk. paper)

1. Nuclear weapons-Government policy—United States. 2. Nuclear

nonproliferation. 3. United States-Military policy. I. Title.

UA23.K77695 2008

$355.02{ }^{\prime} 170973-\mathrm{dc} 22$

2008024573

Typeset by Bruce Lundquist in 10/14 Minion

Special discounts for bulk quantities of Stanford Security Studies are available to corporations, professional associations, and other organizations. For details and discount information, contact the special sales department of Stanford University Press. Tel: (650) 736-1783, Fax: (650) 736-1784 
For two casualties of war: My father, Harry, who worked at the Watertown, Massachusetts, Arsenal during World War II, and the uncle I am named after, Mickey, who died at Anzio. 

Midway this way of life we're bound upon,

I woke to find myself in a dark wood,

Where the right road was wholly lost and gone.

Dante, The Divine Comedy,

Canto I (translated by Dorothy L. Sayers)

The future, which has so many elements of high promise, is yet only a stone's throw from despair.

J. Robert Oppenheimer, letter to Herbert Smith

When the gods punish us, they make us believe in our own advertising.

Daniel Boorstin, paraphrasing Oscar Wilde, in The Image: Or What Happened to the American Dream

And how can we enlarge our opportunities? Can we transmute what appears to be an immediate crisis into a long-term problem, which presumably would permit the application of more varied and better considered correctives than the pitifully few and inadequate measures that seem available at present?

Bernard Brodie, The Absolute Weapon

A pessimist sees the difficulty in every opportunity; an optimist sees the opportunity in every difficulty.

Winston Churchill, origin unclear 
